\title{
Implementation of Pancasila Values in the New Order Era and Post-Reformation
}

\author{
Rahmat Salam \\ Universitas Muhammadiyah, Jakarta, Indonesia \\ rahmat.salam@umj.ac.id
}

\begin{abstract}
Pancasila is the basis of our country and the nation's view of life, which is extracted from the noble values of the nation's culture. However, along with the development of time, the practice and implementation of the Pancasila practice are always adjusted to the regime's will in power. In the Old Order era, Pancasila was used as an ideological tool; during the New Order, Pancasila was carried out purely and consistently but followed the regime's will in power at that time. In the Reformation Age, the implementation of Pancasila, which was expected to be following the original, even began to be abandoned because the people were more faced with a free lifestyle with liberal understanding. This article will try to highlight the position of Pancasila during the New Order regime when President Suharto was in power and compare it with the work of Pancasila Post-reformation starting from the fall of the New Order until now and looking at the challenges that will be faced in the future.
\end{abstract}

\author{
Keywords \\ pancasila; new order; \\ reform
}

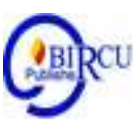

\section{Introduction}

Pancasila contains values and ideals that are excavated from the earth of Indonesia itself, meaning that it is extracted and taken from the wealth, spirituality, morals and culture of the Indonesian people and nation (Muslimin, 2016). Here Pancasila is an open ideology in the sense that Pancasila, as an ideology that can keep up with the times and is dynamic, is an open-minded system and results from the community's consensus. Therefore Pancasila is also the basis of the State which of course must be realized in all aspects. Life of the nation and State (Supritano, 2011). Pancasila is a fantastic political consensus; the country's founders were able to accommodate all existing interests into the Pancasila ideology. Extraordinary was taking the middle way between two extreme options, namely a secular state and a religious state. The state basis determined is a choice that follows the character of the nation, original, which eventually becomes a country with a religious character (Riyanti \& Prasetyo, 2020).

Pancasila is the fundamental ideology of the Indonesian people, namely as the values that underlie all aspects of the social life of the Indonesian people. Pancasila consists of five main joints, namely: (1) Belief in One Supreme God; (2) Just and civilized humanity; (3) the Indonesian Union; (4) Democracy led by solemn wisdom in representative deliberation; and (5) Social justice for all Indonesian people.

Pancasila was officially established as the basis of the Indonesian State and is still being used today (Weatherbee, 1985). Its application differs according to the current period. In every era, Pancasila has developed, especially in interpreting Pancasila itself. During these times, many things were not relevant in applying the noble values of Pancasila as the ideology of the Indonesian nation (Gultom, 2021). The formulation of Pancasila as we know it today is not something sudden or coincidental but from the results 
of deep thought and inseparable from the preparations for independence carried out by BPUPKI, in its first session on May 29 to June 1 1945, discussing the basic formulation of the State. (Maarif, 20090. Thus it is clear that BPUPKI in the first session discussed determining the basis of the State which in the end was established Pancasila, so Pancasila is the foundation of the State and nothing else, not just a pillar but a building basis that determines the shape and form of the building itself (Widisuseno, 2014).

Pancasila as the ideology and basis of this State will not be replaced and changed as long as the Unitary State of the Republic of Indonesia still exists. As stated by the chairman of the Constitutional Court, Arief Hidayat, who indicated that Pancasila could not be changed because it was a crystallization of the soul of the Indonesian nation, which had religious, familial, cooperation, and tolerant characteristics (but on the other hand, in the Pancasila reform era, several children of the nation questioned it. In a crisis that resulted in a downturn in almost all areas of life, Pancasila was made a scapegoat. According to them, only liberalism and capitalism that have been proven to win the world's ideological battle can save Indonesia. The appreciation of these ideologies has dramatically influenced the life of the nation and State. Pancasila and its values fundamental values have been abandoned; even education and its realization in academia had begun to be eliminated regardless of where and when it happened. Prof Muladi (Governor of Lemhanas) stated that awareness and appreciation of the importance of Pancasila as an ideology and ideology The nation's life expectancy is dwindling, especially among the nation's elite. This results from the desire for change in various aspects of life, which tends to lead to chronic deviations. Muhammad Yasin (Secretary-General of the National Resilience Council) said that since the beginning of the reform, the prestige of Pancasila has declined so that the fundamental values of Pancasila have been degraded in its implementation.

Nationalism is interpreted by Acehnese youth as the general understanding of love for the homeland. Which is a feeling of a citizen who is dependent and loves his country. 3 From this understanding, nationalism is portrayed simply but precisely. That being nationalist is an attitude that is aware of the dependence and love for his country which can be realized in several forms. One of them is struggling to make the nation proud. (Fuandi and Anwar, 2018)

From the explanation above, the writer is interested in discussing the history and development of Pancasila from the New Order era to the post-reform period as it is today. Therefore, this research is expected to enrich the scientific treasures about the product of Pancasila between the New Order and the Reformation. Furthermore, this study is expected to be an additional reference for future research.

\section{Research Methods}

To get the basis for theoretical construction, the author uses a qualitative approach with a literature review method regarding fundamental theories about the implementation and practice of Pancasila from the New Order era to the Reformation era. Data used in this study are secondary data, namely data obtained from books, scientific journals, and literature related to this research. Qualitative research is carried out under natural conditions and is inventive. In qualitative research, the researcher is the key instrument. Therefore, researchers must have broad theoretical and insightful provisions to ask questions, analyze and construct objects understudy to be more apparent. This research emphasizes more on meaning and value bound (Moloeng, 2007). Qualitative research where the researcher's role is a critical instrument in collecting data and interpreting the 
data. Data collection tools usually use direct observation, interviews, document studies. While the validity and reliability of the data use triangulation using inductive methods, the results of qualitative research emphasize meaning rather than generalization (Gunawan, 2013).

\section{Results and Discussion}

Pancasila as the Indonesian nation and State ideology is not the result of individual thought which later became an ideology. Soekarno said that Pancasila was excavated from the motherland, and the earth of Indonesia itself, meaning that Pancasila contained the values, morals and culture of the Indonesian nation that had existed since the Indonesian country existed and not an ideology imposed from outside. Even those values are not immediately enforced, but through a long process that is open and democratic. In the end, existing differences can be compromised in a mutual agreement (Shofa, 2016). This means that as an ideology, Pancasila is not closed but places itself as an open ideology (Harefa, 2012). Available doctrine is not only justified; it is necessary. Therefore, open ideology belongs to all people to find themselves, their personalities in that ideology. This available ideology contains fundamental values; in the Stuffen theory of Hans Kelsen, it is in the highest position so that its content is not operational. These values can only be operationalized when they have been translated into decisions that have been given the form of a constitution or other statutory regulations (Kelsen, 1955).

At first, the concept of Pancasila could be understood as a common platform or a common platform for various political ideologies that developed at that time in Indonesia. Pancasila is an offer that can bridge ideological differences among members of BPUPKI (Ruslan, 2013). Pancasila was intended by Soekarno at that time, namely as a common principle so that with that principle, all groups in Indonesia could unite and accept this principle. According to Adnan Buyung Nasution, there has been a change in the function of Pancasila as the state ideology. Pancasila is intended as a democratic platform for all groups in Indonesia. The doctrinal development of Pancasila has changed it from the initial function of Pancasila as a common platform for political ideology and schools of thought following the first formulation presented by Soekarno into an integrated, comprehensive ideology. The ideology of Pancasila is a distinctive ideology, different from other ideologies (Nasution, 2011).

As the basis of the State, Pancasila is essentially the source of all sources of law or sources of legal order (Bo', 2016). This has juridical consequences, namely that all laws and regulations of the Republic of Indonesia must be of the same spirit and in line with Pancasila. In other words, the content and purpose of the Indonesian laws and regulations must not deviate from the heart of Pancasila (Kunantiyorini, 2015). Therefore, based on historical interpretations, as BPUPKI did in its first session, the chairman of BPUPKI Kanjeng Raden Tumenggung Radjiman Wedyodiningrat invited members to determine the basis of the State by asking the question 'what is the basis of the Indonesian state that we are going to form'. Discussions and debates were very fierce, but in the end, it was agreed that the basis of the Indonesian State was Pancasila. Their contents were as stated in paragraph IV of the Preamble to the 1945 Constitution of the Republic of Indonesia.

\subsection{Pancasila in the New Order Era}

The drastic decline in the power of Sukarno and the PKI after the G 30 S/PKI was due to the roles played by the two before. As is well known, Soekarno was very authoritarian, so many were waiting for the momentum to challenge without risking going 
to prison openly. Meanwhile, since 1963 the PKI (when Soekarno repealed the Emergency Law) no longer chose the peaceful way of politics.

Finally, Soekarno issued the Order of March Eleven (Supersemar) 1966, which was addressed to Suharto. The warrant has been a very effective legitimacy tool for the Army to further the political scene. The day after the order was received, Suharto dissolved the PKI, something the community had long demanded through demonstrations. President Soekarno himself practically lost his power after issuing Supersemar, even though he was still officially president in the status of "Constitutional President".

After being cleared of elements of the PKI and Sukarno's supporters, the DPRGR and MPRS began holding their sessions as state institutions. In 1967, the MPRS revoked Soekarno's mandate as president. Soekarno lost his position based on TAP No. XXXIII/MPRS/1967, which also installed Suharto as Acting President. A year later, through TAP No. XLIII/MPRS/1968, Suharto was appointed the definitive president.

The new regime that emerged above the collapse of guided democracy called itself the 'New Order'. What appeared as the main character of the New Order was the Army. There is a constitutional basis for the entry of the military into politics, namely the 1945 Constitution, which stipulates the existence of the ABRI group in the members of the People's Consultative Assembly (MPR). To gain dominance in the DPR, the government proposes the appointment of some members of the DPR by the government. In addition, the government wants district system elections. The parties that participated in discussing the draft law in the DPR rejected the government's proposal, both regarding the appointment of DPR members and the electoral system.

One model that is considered to explain the political reality of the New Order is the bureaucratic authoritarian regime, which deviates far from the noble values of Pancasila. In a government like this, decisions are made in a simple, precise, straightforward, efficient way and do not allow for a long gain (Apriliani \& Dewi, 2021). The emergence of this regime was due to a kind of delayed-dependent development syndrome among the political elite, such as dependence on the international system and domestic political unrest. Moreover, this regime is supported by the groups that can best help an efficient development process, namely the military, civilian technocrats, and owners of capital (Hidayat, 2008|).

The New Order's determination to guarantee political stability in the context of economic development had implications for parties' lives and the role of the people's representative institutions. The New Order government was determined to correct political irregularities in the Old Order era by restoring political order based on Pancasila. The assertion that political stability is a prerequisite for economic development can indirectly have implications for reducing the pluralism of political life or limiting the democratic political system. At the beginning of its existence, the New Order began its government with a libertarian style. The New Order has shifted Indonesia's political system from the extreme point of authoritarianism in the era of guided democracy to a liberal democratic system. However, the libertarian style did not last long because apart from being a reaction to the previous authoritarian system, this system was only tolerated as long as the government sought a new form of Indonesian politics. As soon as the new format was formed, the liberal system shifted again to an authoritarian system (Hadi \& Kasuma, 2012).

President Suharto led the New Order regime. During the New Order era, the government wanted to implement Pancasila and the 1945 Constitution purely and consistently as a criticism of the Old Order, which deviated from Pancasila, through the P4 program (Guidelines for Understanding and Practicing Pancasila). The New Order government succeeded in maintaining Pancasila as the basis and ideology of the State and 
at the same time succeeded in eradicating communist ideology in Indonesia. However, the implementation and application are very disappointing. Several years later, the policies issued were not following the spirit of Pancasila. Pancasila is interpreted according to the interests of government power so that it is closed to other interpretations. Pancasila is used as indoctrination. President Suharto used Pancasila as a tool to perpetuate his power.

There are several methods used in the indoctrination of Pancasila. First, through P4 teaching, which is carried out in schools through debriefing. Second, President Soeharto allowed the people to form organizations on the condition that they must be based on Pancasila, or what is known as the single principle. Third, President Soeharto forbade any criticism that could bring down the government on the grounds of stability because President Soeharto assumed that criticism of the government caused domestic instability. Therefore, to maintain the country's strength, President Soeharto used military force so that no party dared to criticize the government.

In his system of government, President Soeharto committed several irregularities in the application of Pancasila, namely by implementing centralized democracy, democracy centred on the government. In addition, President Soeharto also has control over the executive, legislative, and judicial institutions, so that the regulations made must be following his approval. President Soeharto also weakened democracy, especially the press, because it was seen as endangering his power. Thus, President Soeharto established the Ministry of Information as a censorship agency on a large scale so that any news published in the media would not bring down the government. Another very bad deviation that deviates from the noble values of Pancasila is that President Soeharto perpetuated Corruption, Collusion and Nepotism (KKN) so that at this time, it was known as the most corrupt regime in Indonesia.

The peak was when the economic and monetary crisis occurred in 1997, which caused the Indonesian economy to plummet, triggering a massive movement to overthrow the New Order regime under the leadership of President Soeharto. During the New Order regime in power, several actions by the authorities deviated from the noble values of Pancasila, including:

1. Keep President Suharto in power for 32 years.

2. There is a unilateral interpretation of Pancasila through the P4 program.

3. There is ideological oppression, so that people who have creative and critical ideas are afraid to speak out.

4. There was physical oppression, such as the killings in East Timor, Aceh, Irian Jaya, the Tanjung Priok case, the July 27 vandalism case, etc.

5. Discriminatory treatment by the State against non-indigenous people (descendants) and minority groups.

\subsection{Pancasila in the Age of Reform}

The reformation period began when Suharto resigned from his position and was replaced by B.J. Habibie. During his reign, B.J. Habibie tried to improve the economic system, reform the political and legal fields and issued Law Number 9 of 1998 concerning Freedom to Express Opinions in Public. However, starting during the reformation period, the implementation of Pancasila as the state ideology continues to be echoed to this day. However, efforts to replace the Pancasila ideology with other ideologies have also decreased (Ratnawati, 2017).

In reality, the Indonesian people have misinterpreted the meaning of the word "reformasi", which is currently giving rise to a movement in the name of reform, even though the trend is not following the meaning of reform itself. For example, when the 
community can only sue by carrying out anarchic actions, in the end, there will be the destruction of public facilities, resulting in innocent victims. Therefore, in carrying out the reform movement, the public must know and understand the meaning of reform itself so that carrying out reform is following the objectives of the reform.

Pancasila is the basis of the Indonesian State philosophy as a way of life for the Indonesian people. Still, it turns out that Pancasila is not placed in its position and function. During the Old Order, the implementation of the State experienced deviations and even contradicted Pancasila. For example, the president is appointed for life who is dictatorial. During the New Order era, Pancasila was only used as a political tool by the authorities. Every citizen who does not support the policies of the sources is considered contrary to Pancasila. Therefore, the reform movement must be included in the framework of Pancasila as the basis for the ideals and ideology of the nation so that anarchism does not occur, which destroys the country and State.

The existence of Pancasila is still widely interpreted as a political conception whose substance has not been able to be realized in real terms. Reform has not been going well because Pancasila has not fully functioned as it should be. Many people memorize the points of Pancasila but do not understand the real meaning. In the Reformation Era, Pancasila as a re-interpretation, namely Pancasila, must constantly be reinterpreted following the times, meaning that interpreting it must be relevant and contextual and must sync or follow the reality of it the era at that time. Various changes were made to improve the nation's life and State under the umbrella of the Pancasila ideology. However, the fact is that there are still many unanswered socio-economic problems (Agus, 2016).

Pancasila is the Reformation Era is not much different from Pancasila during the Old Order and New Order, namely there are still challenges that must be faced. The challenge is Corruption, Collusion and Nepotism (KKN), which to this day has no end. At this time, corruption is rampant. State officials who commit corruption are no longer ashamed. On the contrary, they feel proud, shown when the official came out of the KPK building by waving and smiling like a newly famous artist. In addition, globalization is a challenge for the Indonesian people because the Pancasila ideology is increasingly being eroded by liberalism and capitalism. Moreover, the challenges at this time are open, accessible, and honest.

The collapse of the new order, resulting in a phobia of Pancasila. The basis of the country, admired initially by many, seemed to have been forgotten for a while because it was almost always synonymous with the New Order regime. As if the exclusion of Pancasila did not appear to have a significant negative impact. Still, day by day, the effect is increasingly felt and has a fatal impact on the life of the nation and State. In social life, people lose control over themselves, resulting in massive horizontal and vertical conflicts, which weaken the foundations of the unity and integrity of the Indonesian nation and State. In the cultural field, public awareness of the nobility of the culture of the Indonesian country began to fade, which in the end led to a disorientation of the nation's personality, which was followed by the moral destruction of the younger generation (Fauzan et al., 2021).

This condition makes various groups of people concerned, including scholars and state officials who care about this. Around 2004 Azyumardi Azra initiated the rejuvenation of Pancasila as an integrative factor and one of the fundamentals of national identity (Azra, 2004). The call seemed significant because amending the 1945 Constitution of the Republic of Indonesia gave rise to the Jakarta Charter. Terrorist movements also hit Indonesia in the name of religion. Not long after, symptoms of Sharia regulations appeared in several regions. The series of symptoms seemed to complement public anxiety during 
the reformation, which questioned the direction of the reform and democratization movement. Azyumardi's call was responded to by several groups. The discourse on Pancasila has warmed and expanded again after the Symposium on the Commemoration of the Birthday of Pancasila, which was held by FISIP - UI on May 31, 2006. However, the level of implementation is still far from expectations, the chaos of politics, the economy, the moral decline of the younger generation, the rampant abuse of illegal drugs, and widespread corruption. Relentlessly, showing that the values of Pancasila do not touch the spiritual mentality, the energy of Pancasila does not move in this realm.

Many state administrators, law enforcers, and political elites have been proven to have committed corruption. So before that, they had to target Pancasila to the heart, especially if it was confirmed that corruption was proven (Kompas, 2017). However, for the long term, the target of Pancasila education through education is still very much needed. Even though it still raises question marks, President Joko Widodo meant to form the Presidential Working Unit for the Development of Pancasila Ideology (UKP - PIP). Government Regulation instead of Law No. 2 of 2017 concerning Social Organizations is also the government's effort to prevent organizations that will erode Pancasila values legally. As the basis of the State, the nation's ideology and the State, the glue of the country, Pancasila must always be maintained and instilled in all Indonesian people. As stated by Jimmy Asshiddiqie, since the reformation, many people, especially the younger generation, have misunderstood the relevance of Pancasila today, let alone the future. This assumption is wrong; what many people have complained about from the past is the act of abusing Pancasila for the sake of power, not the existence of Pancasila itself as a philosophy of life and a mirror of the shared dream of all the nation's children about living as a nation and State that we idealize together (Latif, 2011).

Since the New Order was overthrown by the reform movement, Pancasila, as the ideology of the Indonesian nation, has lost its established place. There is a kind of phobia and allergy among the people of this nation-state to recognize Pancasila, let alone try to examine it. Although this country still maintains a consensus by declaring Pancasila as the nation's ideology. But in fact, it seems we have to question it again. Because at this time, the debate about whether or not Pancasila is still relevant as an ideology is still happening. It has been several years since Indonesia has entered the reform era. Various changes were made to improve the nation's life and State under the umbrella of the Pancasila ideology. However, the fact remains that there are still many unanswered socio-economic problems. The existence and role of Pancasila in reform were also questioned. Can Pancasila provide better hope for this country? Judging from the facts, it's worrying. Reform has not been going well because Pancasila has not fully functioned as it should be.

The existence of Pancasila in this reform era should be the basis, reference or new paradigm. Pancasila is the basis of the State following the main ideas contained in the 1945 Constitution. But now, this nation often neglects Pancasila. Whereas the actual reformation implements or practices Pancasila for the life of the country, state and society. With the spirit of Pancasila, the reform movement should be able to mobilize unity to fix the current multidimensional crisis. No one group can win reform without accordance with other groups. The experience of failure and bottlenecks of the reform movement so far has proven this. With unity step by step, the reform movement will be expected to bring Indonesia into a democratic country, strong and peaceful, safe, peaceful and just and prosperous. Please keep in mind: "Unity is what brings us to greatness and independence." 


\section{Conclusion}

During the New Order Period, there was a need for determination to implement Pancasila purely and consistently as a correction for the implementation that was distorted during the Old Order era where Pancasila was only used as a tool to perpetuate the power of President Sukarno with the appointment of a president for life. And the Practice of Pancasila (P4) is again used as a tool to perpetuate the power of President Suharto. In the Post-Reformation Era, it is hoped that Pancasila can be practised correctly and adequately following the noble values of the Indonesian nation. But in reality, it is precisely in this reform era that the Indonesian country is felt increasingly far from the noble values of Pancasila, where the Indonesian people are experiencing liberalism with all the freedoms due to the influence of globalization.

\section{References}

Agus, A. A. (2016). Relevansi Pancasila sebagai ideologi terbuka di era reformasi. Jurnal Office, 2(2), 229-238.

Apriliani, S. L., \& Dewi, D. A. (2021). Menyingkap Perkembangan Pengimplementasian Pancasila dari Masa ke Masa. EduPsyCouns: Journal of Education, Psychology and Counseling, 3(1), 21-30.

Azra, A. (2004). Rejuvenasi Pancasila dan Kepemimpinan Nasional. Kompas.

Bo'a, F. Y. (2018). Pancasila Sebagai Sumber Hukum Dalam Sistem Hukum Nasional. Jurnal Konstitusi, 15(1), 21-49.

Fauzan, A., Kurniawansyah, E., \& Salam, M. (2021). Pengembangan Buku Revitalisasi Dan Reaktualisasi Pancasila Dalam Kehidupan Berbangsa Dan Bernegara Menghadapi Tantangan Globalisasi. Jurnal Civic Education: Media Kajian Pancasila dan Kewarganegaraan, 4(2), 43-51.

Fuandi and Anwar. (2018). Nationalism and the Challenge of Globalization for the Young Generation in Aceh and Riau. Budapest International Research and Critics InstituteJournal (BIRCI-Journal). P. 151-160.

Gultom, A. (2021). Implementasi Pancasila dalam Menjaga Eksistensi Bangsa. KAIS Kajian Ilmu Sosial, 30(1), 55-66.

Gunawan, I. (2013). Metode Penelitian Kualitatif. Jakarta: Bumi Aksara, 143.

Hadi, D. W., \& Kasuma, G. (2012). Propaganda Orde Baru 1966-1980. Media Verleden, $1(1), 1-109$.

Harefa, A. (2012). Pancasila sebagai Ideologi Dinamis. Didaktik: Jurnal Ilmiah Pendidikan, Humaniora, Sains, dan Pembelajarannya, 6(2), 879-891.

Hidayat, H. (2008). Politik Lingkungan: Pengelolaan Hutan Masa Orde Baru Dan Reformasi. Yayasan Obor Indonesia.

Kelsen, H. (1955). Foundations Of Democracy. Ethics, 66(1, Part 2), 1-101.

Kunantiyorini, A. (2015). Pancasila Sebagai Sumber Segala Sumber Hukum. Pena Jurnal Ilmu Pengetahuan Dan Teknologi, 26(2).

Latif, Y. (2011). State Plenary: Historicity, Rationality And Actuality of The Pancasila. Jakarta: Gramedia.

Maarif, A. S. (2009). Islam Dalam Bingkai Keindonesiaan Dan Kemanusiaan: Sebuah Refleksi Sejarah. Mizan Publika.

Moloeng, L. J. (2007). Metodologi penelitian kualitatif edisi revisi. Bandung: Remaja Rosdakarya. 
Muslimin, H. (2016). Tantangan terhadap pancasila sebagai ideologi dan dasar negara pasca reformasi. Jurnal Cakrawala Hukum, 7(1), 30-38.

Nasution, A. B. (2011). Towards Constitutional Democracy in Indonesia. Unimelb.

Ratnawati, T. (2017). Political Reform In Indonesia After Soeharto. Masyarakat Indonesia, 36(2), 245-266.

Riyanti, D., \& Prasetyo, D. (2020). Internalisasi Nilai-Nilai Pancasila di Perguruan Tinggi. Citizenship Jurnal Pancasila dan Kewarganegaraan, 7(2), 82-96.

Ruslan, I. (2013). Membangun Harmoni Kehidupan Berbangsa dan Bernegara dengan Nilai Islam dalam Pancasila. Jurnal Tapis: Jurnal Teropong Aspirasi Politik Islam, 9(2), 1-16.

Shofa, A. M. I. A. (2016). Memaknai Kembali Multikulturalisme Indonesia Dalam Bingkai Pancasila. JPK (Jurnal Pancasila Dan Kewarganegaraan), 1(1), 34-40.

Supriyatno, A. (2011). Pancasila Sebagai Ideologi Terbuka. Dalam Edukasi: Jurnal Penelitian \& Artikel Pendidikan, 3(6).

Weatherbee, D. E. (1985). Indonesia In 1984: Pancasila, Politics, And Power. Asian Survey, 25(2), 187-197.

Widisuseno, I. (2014). Azas Filosofis Pancasila Sebagai Ideologi Dan Dasar Negara. Humanika, 20(2), 62-66. 